\title{
HUMAN DIGNITY AS A NEW CONSTITUTIONAL VALUE OF THE CONSTITUTIONAL SYSTEM OF REPUBLIC OF CROATIA
}

DOI: $10.47743 /$ rdc-2016-3-0003

Dubravko LJUBIĆ, Dr.sc.

The Constitutional Court of the Republic of Croatia, Senior legal adviser-menthor; Head of the Preliminary investigation procedure department

\section{Abstract}

The study presents the human dignity as the basis of every legal order, its ethics and all the other factors that make a legal system just, a condition for the existence of rights in general. Croatian Constitution does not recognize human dignity as the highest value and the basis of design of the basic legal sphere, but, by accepting the Charter of Fundamental Rights of the European Union human dignity is not becoming just the source and means of interpretation of the basic legal sphere, but it is also becoming the basis for establishing relations between the individual and the state and individuals themselves

Keywords: human dignity; the Charter of Fundamental Rights of the European Union; constitutionalization of the law; European Union

\section{Introduction}

As a result of attempts to prevent new war destruction after World War II there is a notable incidence of plural integrative intentions on the European continent. In doing so, advocates of the European confederation have gradually recoiled from the factual evolution of ideas that strived towards forming a new and unique social form that would cover the entire Old Continent. However, the idea of European constitutionality has expectedly collapsed and ended with the refusal of acceptance of the constitutional document of the European Union in referenda held in Netherlands and France. This is because the development of the constitutionality is favored by relative stability of the basic elements inherent to a country, namely the territory, government and population. Constitutionality is benefited by the existence of a clear vision of structure, which should be determined or confirmed by a constitution. All these elements currently have no structure in the European Union whose stability would be the guarantor of success at attempting its general constitutionalization. European Union has not yet fully defined its 


\section{Dubravko LJUBIĆ}

borders, and its final spatial form is still unknown due to the fact that the list of candidates for membership is not closed. At the same time, within the Union, the primacy of national sovereignty of member states, above the supranational one, still seems strong and unquestionable. Moreover, neither does the existence of a general mood of the inhabitants of Europe focused on belonging to a future and a new European entity seem as an imminent and certain option. In general, the reasons for the failure of this constitutional document can be divided into legal and political ones. Legally, organizational forms of European Union member states range from republics to parliamentary monarchies, from the unitary to the complex states, with some knowing constitutionality in its material sense, while others do not. On the other hand in the development of legal systems Anglo-Saxon, Germanic and Romance legal circles intertwine with those occurring in the countries that were members of the former Warsaw Pact, whereby the diversity of constitutional texts and institutional forms of individual member states is huge. In such circumstances the offered text had no real chance because of its intentions towards comprehensiveness, thereby losing sight of the fact that at the creation of legal texts dependent on consensus only indisputable subjects should be covered. Politically speaking, however, the European Union has resulted from associations that were created from common interests. Earlier by interest agreed evolutionary development of mutual relations of Member States could hardly result with any significant friction in their relations. However, by expansions committed after 2004, the Union's membership included countries with different degrees of development and due to this fact, diverse interests. This situation inevitably had to give birth to disagreements in the life of the European Union, ones between the old and new members, large and small ones, developed and undeveloped, densely populated and those who are not, economically powerful and those who require financial assistance.

After a failed attempt at constitutionalization, a solution for bridging the overall crisis in maintaining a functioning Union as a whole was found in complementing the legal basis on which the European Union rests. Thus, instead of the Constitution, the Union received another Lisbon Treaty on December 13, 2007, with the ratification procedure completed by November 3, 2009 and which came into force on December 1, 2009. But how much did the Lisbon Treaty really fulfill its role, we are witnessing the daily political activities of the institutions of the European Union that have been reduced to making compromises between Berlin, Paris and London sent to perform tasks of rescuing what is too big to collapse. This is because the consequences of the collapse of the current system can be substantially more important than the cost of maintaining the European unity. Constitutionally speaking, the difference between the nature and scope of unaccepted constitutional text and a ratified document is huge. The Constitution generally shapes in full the principles of the legal and social system of some social structure whereby its norms are basic and as such require of all other rules and structure to be in harmony with them. Constitutional provisions form a whole and 
Human dignity as a new constitutional value of the constitutional system...

represent the highest-ranking source of law that is elaborated in legal acts of lower legal force. International agreements in turn, as well as all other agreements, will represent a consensus of the parties which is directed towards the achievement of the permitted legal effect within the framework of voluntary commitments. They regulate only those matters that are covered by the will of the parties, while their content is an obligation on the parties that have recognized them by the act of ratification. In the national legislation, international agreements operate on the legal basis contained in the constitution, which determines their reception, acceptance and position in relation to other standards of domestic law. This position can also have a force superior to statute, but it is always lower than the constitution. This is because the norms of international law stem their strength and position within the national legislation from the constitution, so it is therefore logical that they are subordinate to it.

\section{Charter of Fundamental Rights of the European Union}

The protection of fundamental human rights and freedoms is a question of great importance for every inhabitant of the European Union. In order to regulate matters related to the protection of fundamental human rights and freedoms, at the international conference in Nice ${ }^{1}$, members of the European Union adopted the Charter of Fundamental Rights of the European Union. The Charter initially represented a systematic catalog of human rights and freedoms that otherwise make the legal system of the Union². At that time it was not the source of rights nor constituted an international treaty or some other form of a catalog of fundamental rights and freedoms which would enjoy judicial protection. However, from the beginning, it was an extremely important source of information about the standard of human rights in the European Union, which on one hand is set as a goal for the state planning of the Member States, while on the other hand it provides the inhabitants of the European Union with an insight into the level of protection of human rights, which can be expected in the context of the European Union. Subsequently, the Charter was signed and solemnly proclaimed on December 12, 2007 in Strasbourg. After the entry into force of the Lisbon Treaty the Charter has received a legally binding force in 26 Member States $^{3}$. By including the contents of the Charter in the Lisbon Treaty its role has grown

\footnotetext{
${ }^{1}$ Held on December 7, 2000.

2 General principles of this Charter have been built into the fundamentals of the European Union on the basis of Article 2 of the Treaty on European Union, which reads that the Union is founded on the principles of liberty, democracy, respect for human rights and fundamental freedoms, the rule of law, principles which are common to Member States. These principles must be observed by all the countries wishing to join the European Union on the basis of Article 49 para. (1) of the Treaty, which states that any European country which respects the principles contained in Article $6 \S 1$ of this agreement may apply for membership in the European Union.

${ }^{3}$ A reservation to the contents of the Charter was filled by Poland and U.K.
}

CONSTITUTIONAL JURISDICTIONS 


\section{Dubravko LJUBIĆ}

beyond an exclusively interpretative role in the application of Community Law and it has become a source of law in the field of protection of fundamental rights and freedoms ${ }^{4}$.

By examining the contents of the Charter of Fundamental Rights of the European Union we see that it covers the classic fundamental rights of the first generation in a way and in the content that is not different from those established directly after the French Revolution. However, innovation is the definition and regulation of the social segment of fundamental rights. In fact, the development of the world economy and utter globalization, economic migration and the limited number of jobs and existential problems caused by limited sources of funds have pushed in the forefront the fact that certain social groups deserve special social care. The Charter considers such care as critical for nonproductive population as well as for the parts of the population which for various reasons have a reduced production power. In addition to the preamble, it covers human dignity, then the principles of freedom, equality and solidarity and justice. In addition, the Charter in the part called "Rights of Citizens" elaborates the provisions on special rights which are within the Union recognized for nationals of Member States or citizens of the European Union. Common provisions are broken down in the last section of the Charter.

According to the wording contained in the preamble the Union is founded on the universal values of human dignity, freedom, equality and solidarity. The content of those universal values is in turn interpreted in accordance with the range of the principle of democracy and the rule of law, and in accordance with standards which are by these terms established by constitutional traditions of the Member States and the judgments of supranational courts ${ }^{5}$. From the specified determination it follows that the Charter is based on three classic sources of protected goods. Human dignity as a source of rights deriving from the human essence. Freedom as a source of protection of all activities of a person, which are resulting from the fact of its positioning in the social community. Equality as a universal principle of how authorities treat the individual and the basis of the state with the rule of law. In addition, the Charter as an upgrade to the classic catalog of human rights established by the Universal Declaration of Human Rights of the United Nations, expanded by the protocols to the European Convention on Human Rights and Fundamental Freedoms, introduces the principle of solidarity as the basis of family, labor and social legislation of the Union.

\footnotetext{
${ }^{4}$ See H.W. Regeling, Grundrechtschutz in der EG, München, 1993, pp. 16-164, or T.C. Hartley, Temeljna prava Europske Zajednice, Rijeka, 1999.

${ }^{5}$ Section 2 and 6 of the preamble.
} 


\section{Human dignity as a new constitutional value of the constitutional system...}

\section{Reception of international law in constitutional and legal order}

\section{of the Republic of Croatia}

At the constitutional level it seems reasonable to ask the question what actually shapes the Union. Due to disagreements over the adoption of a common system of basic standards, today Union's legal framework is a set of legal rules of various legal ranking and obligation, in which totality not all Member States are obliged in the same way to look for a legal basis for shaping their society. It therefore seems inevitable and socially justified, in order to preserve the rule of law in the domestic constitutional system, to still give primacy to the national constitutional arrangements. Not as an expression of euroscepticism, but as the constitutional importance of preserving the coherence of ones own constitutional system. During the accession negotiations and after gaining full membership the Republic of Croatia has very seldom previously or subsequently raised the question of whether all direct commitments, such as those implemented through the activity of the legislature, are in line with the Croatian Constitution. As if it is forgotten that the Constitution is the system of the most basic norms of a society because it represents the source of the totality of national and international law. It is a result of evolution of concentrated collective constitutional empiricism of a society, or an expression of popular will and the will of the constructed political theory ${ }^{6}$. Its general and sometimes undefined solutions do not make sense if they are devoid of impact on real life. The Constitution should be a tool in the hands of citizens for arranging their attitude towards the authorities by exercising their rights. It remains a dead letter on paper if the public is not interested in its content and implementation. The constitutional principles and ideals can be realized only in a society whose members believe that the constitutional arrangements are established for the benefit of all. Opinio constitutionis is the foundation of the functioning constitution based on the conscious support of the democratic public. Every holder of government should deal with the constitutional truth regardless of the fact of existence of democracy in its present formal majority form. To make the Constitution efficient, it must be based on public trust in its accuracy. Confidence in the constitution is created and maintained exclusively in social formations in which its content respects and protects all of the anomalies arising from the societies, but also from all influences from the outside that act contra constitutionem. The constitution of the dam which citizens use to bind the government with the chains of the rule of law. A that dam can be effective only in systems that hold to the rules that they themselves have created in a way that avoids excess situations between the legal rules of the same or different level ${ }^{7}$.

\footnotetext{
6 See B. Smerdel, O ustavima i ljudima, Uvod u ustavnopravnu kazuistiku, Novi informator, Zagreb 2012, pp. 49-52, and idem, Hrvatska ustavnost u Europskoj uniji: državna zajednica ili zajednica novog tipa, in Hrvatska pravna revija no. 9/2012, pp. 1-8.

$7 \mathrm{~T}$. Jefferson, On trust rather than distrust of government, we are building a political community in which the holders of government are tied down by chains of constitutionality, so that they do not abuse that power in their favor, at the expense of the community.
}

CONSTITUTIONAL JURISDICTIONS 
Basis of its interpretation the Croatian Constitution determines in the content of Article $3^{8}$, which establishes the highest values of the constitutional order. With this definition several circumstances seem obvious. Firstly it is chaotic enumeration of content vague terms devoid of the necessary systematization. After the framers of the Constitution have as the foundation for the interpretation of the constitution defined the principles of freedom, equality and formulation of the duty to respect human rights, specific constitutionally protected goods are sets forth, which are in the Constitution anyhow as the subject of special treatment, to finish everything with the conclusion on the shaping of Croatian society as a multi-party and democratic, based on the rule of law. On the other hand the provisions of Article 3 of the Constitution do not contain an indication of any circumstances that would establish a certain sphere of the individual protected from the impact of anyone because of the reason that this individual is considered to be a person and arising from his being and existence. Furthermore, the Constitution does not specify a single value that would be immanent to a person, regardless of the social conditioning of the content of its appearance in society. In conclusion, Article 3 of the Constitution does not derive guidelines on the basis of which we could determine the minimum that makes the concept of a human being, with whose harming an individual undoubtedly loses attribute of humanity, and there is no standard by which one could carry out the differentiation of content of protection of constitutional rights ${ }^{9}$ from all other constitutionally protected goods.

Also of note is that even the Croatian Constitutional Court through its practice regarding the protection of the basic legal sphere did not generate standards that would affect the determination of the general and the minimum content of constitutional rights. This is because its recent praxis yields greater attention to the form of proceedings arising from the contested measures of state power than it would focus its deliberations to contents that could colloquially be brought down under the term "substantive constitutional rights". From the practice of the Constitutional Court, it is clear, in spite of the fact that the Republic of Croatia is a member of the European Union, that it has not yet adopted any decision in which it would observe a constitutional suspected situation through the prism of the content of the Constitution and the Charter, although this would not be the original venture in view of a rich constitutional practice of other constitutional courts whose catalogs of constitutional rights and constitutional protection systems of the basic legal spheres correspond to that applicable in the European Union.

\footnotetext{
${ }^{8}$ Freedom, equality, national equality and gender equality, peace, social justice, respect for human rights, inviolability of ownership, conservation of nature and the environment, and a democratic multiparty system are the highest values of the constitutional order of the Republic of Croatia and the grounds for interpretation of the Constitution.

${ }^{9}$ Under the concept of constitutional law I here understand, the basic norm of a society or through that norm by international law established inviolable autonomous sphere of each member of society, immanent to person as a human being, which enables it the recognition as a human and social being and that it enjoys, regardless of its status and other personal characteristics, protection from encroachment by any governmental body.
} 


\section{Human dignity as a new constitutional value of the constitutional system...}

Croatian Constitution has experienced several changes from its original form. Empirically it can be concluded that a certain part of the changes has caused more problems than they have contributed to the consistency of our constitutional system. In particular, indicated is the effect of changes that had not been properly prepared and conducted ${ }^{10}$. We consider the constitution as a set of basic norms that shape a certain social creation and does not draw its strength from a grammatical expression. The core of the constitution is the interpretation of its components and their ranking within the basic norms. This is because all constitutional provisions do not have the same value and are not of the same rank. In particular we need to distinguish the basic provisions that bind the legislator from those who bind the legislator but also the framers of the constitution. The latter ones represent a value based on the particular constitutional structure which does not tolerate limits or regression. Any changes to the constitutional text must respect the basic constitutional principles and be in harmony with them. Unfortunately, in recent years we have witness the fact that nobody is dealing with the serious changes in the constitutional order caused by Croatian accession to the European Union.

One of the most consequential novelties of the membership in the European Union in our constitutional order is the establishment of human dignity as the highest value of the basic legal sphere. Croatian Constitution does not recognize human dignity as the highest value and the basis of design of the basic legal sphere. The concept of dignity enshrined in Article 35 of the Constitution is reserved to the domain of value judgment of one's life and position in society and does not describe the minimum content that every person is guaranteed by its humanity. However, by accepting the Charter of Fundamental Rights of the European Union human dignity is not becoming to us only the source and means of interpretation of the basic legal sphere, but it also becomes the basis for establishing relations between the individual and the state and among individuals themselves. As such, human dignity becomes the complement to the notion of the rule of law and the welfare state. At the same time it becomes a new prism through which one must observe the compliance of positive law, and further legislative measures with the requirements that are placed before the legal system by a constitution based on human dignity as a starting premise of the existence and protection of the basic legal sphere. By introducing the concept of human dignity into our constitutional order, the legislator has also set higher criteria for determining the attitude of the person and the country that the legislation must respect. Another important consideration is to appreciate this new standard in the normative activity that has been delegated to the executive in order to enforce the law. Society can no longer be satisfied by the existence of formal democracy and government understood according to the Aristotle's model of cyclical rule over others, but rather as a public service aimed at achieving the common good and the realization of genuine rule of the

${ }^{10}$ See D. Ljubić, Promjene Ustava i narodna inicijativa, in Hrvatska pravna revija br. 11/2013, pp. 1-11.

CONSTITUTIONAL JURISDICTIONS 


\section{Dubravko LJUBIĆ}

people. In such situations, the realization of the constitutional role of human dignity is practically impossible.

Every social order shaped by the law is the legal system. It does not contain a moral assessment of whether the social community that it shapes is good or fair. Law and justice are two different concepts. The concept of law is exhausted in the description of positive law, and the concept of justice is subject to the development philosophy of law. Law can exist independently of justice. It is a product of the state as the apparatus of coercion, it is illusory to try to equalize even the colloquially law and justice. The tendency of equalization and identification of the concepts of law and justice serves as a political justification for a particular social order as morally justified. However, such an understanding of the terms of law and justice has its source and target in political considerations rather than the rule of law. Law represents a limitation because it determines the rules of conduct of addressees. It is therefore logical to conclude that there is no legal system that provides happiness to every individual, if the definition of the concept of happiness is approached in terms of individual subjectivity, and if by happiness it is understood what that term subsumes under each addressee of legal norms respectively. This is because the perception of happiness of an individual, as a rule does not correspond in the scope and content with the notion that others attribute to that concept. The legal system can not be fair even when trying to achieve the highest possible level of happiness in the widest possible circle of addressees. Happiness that the legal system can provide is happiness in the collective sense of the term, and the legal system can ensure that the individuals have the satisfaction of those needs for which the society represented by democratic rule has by norm ordered to be satisfied in the manner and to the extent specified by law ${ }^{11}$.

But regardless of principled correctness of the above, when we talk about the basic legal sphere of the individual it is not sufficient to observe the state as a social creation which considers each procedure justified by the very fact that it is legal and that it has its foundation in the positive law. Today, this concept could not function without a great danger for the general democratic heritage. The modern concept of a constitutional state requires that in the exercise of power state bodies, besides legality and legitimacy, also have the constitutional approval and justification for action in this particular case. Government actions are not legitimate based on the mere fact that they are undertaken by state authorities in accordance with the law, but the justification of any particular procedure or action of an individual or general act must be appreciated based on the justification of its contents. In other words, the government does not acquire legitimacy only by its existence nor are the actions by government bodies considered legitimate by virtue of being legal. The concept of the modern constitutional state is based on the idea according to which the actions of state authorities must be constitutionally justified by the content and purpose of their undertaking, and their source must be drawn from

${ }^{11}$ See H. Kelsen, Opća teorija prava i države, in Arhiv za pravne i društvene nauke, Beograd, 1951, pp. 18-21.

\section{CONSTITUTIONAL LAW REVIEW}




\section{Human dignity as a new constitutional value of the constitutional system...}

the positive universal values arising from the evolution of the human race. Only thus conditioned performance of public affairs enables the transition from understanding the existence of government as a coercive apparatus over the addressees into the existence of government as an instrument to perform a public service, or as activity which creates and provides the necessary conditions for meeting the everyday needs of individuals and the development and prosperity of the community as a whole. In terms of modern cultural development of society the state power is primarily transformed into public service with the task of ensuring the conditions necessary for the progress of society. Public power is transformed into institutionalized function of the execution of public service or as a service of citizens, while the country undergoes a conceptual integration of the traditional principle of legality in the exercise of constitutionally regulated public services of the welfare state ${ }^{12}$. Therefore, when setting standards for the protection of constitutional rights it is necessary to determine the minimum content free from any public or private influence. The content of the constitution, as the top of the pyramid in legal geometry, must have its philosophical logic which is subordinated to all the legal rules of lower legal force that derive from it. Its contents should be interpreted complementary and consistent with purely descriptive social formations that it shapes, but also with the desired projection of society to which it strives as the ideal.

\section{Human dignity as a constitutional category}

The greatest tradition in the elaboration of the concept of human dignity is found in the German jurisprudence. The need for the introduction of these standards in the constitutional order of Germany is the result of empirical knowledge of the shortcomings of mere declarations of the basic legal sphere, as this was for example done in the Weimar constitution and that has contributed to the escalation of overall discrimination in the Nazi era. In the German hierarchy of regulations the Basic Law of May 23, 1949 is the highest legal basis for the organization of social relations, and thus the arrangement of the basic legal sphere ${ }^{13}$. The Basic Law is the first constitution in

\footnotetext{
12 See D. Rosenbloom, Public Administration and Law, New York, Basel, 1982, pp. 3-4.

13 The term "grundrechte" derives from the German tradition and draws on the concept of "grundgesetz". Fundamental rights are constitutionally guaranteed human rights and freedoms that are defined and guaranteed by the highest legal act. These should be distinguished from the concept of "basic rights" in common law. Here the concept of "basic rights" means the preceding foundation for the state and the constitution which equates its content with the concept of "natural rights". The Basic Law recognizes fundamental rights as an above positive law, which tie the framers of the Constitution themselves. The Basic Law contains only positive fundamental rights. Subjective fundamental rights can also exist exclusively within the constitutional order. Even the framers of the Constitution are bound by the above positive fundamental principles of law which lie ahead of any written law. See V.A. Baruzzi, Geschichtliche Grundbegriffe, Book II, Stuttgart, 1975, p. 1075; R. Alexy, Theorie der Grundrechte, Frankfurt am Main, 1994, pp. 6-25; P. Häberle, Verfassungsgerichtbarkeit, Darmstad, 1976, p. 14; K.G. Zierlein, Sudski (ustavnosudski) nadzor njemačkog Saveznog ustavnog suda i njegova uloga u zaštiti ljudskih prava, Novi Vinodolski, 1998, p. 4; B. Kostadinov, O Ustavu Savezne Republike Njemačke, in Informator br.5964/4.5.2011, pp. 2-3.
} 


\section{Dubravko LJUBIĆ}

which human dignity has taken the most important place of all the other principles on which a constitutional order is based ${ }^{14}$. Human dignity is defined as the highest institutional principle and the highest legal value and a starting point from which all the other fundamental human rights are derived. At the same time, it is a principle which represents a barrier for the state to dispose of the content of any other fundamental right, using such limitations as are set forth by this other fundamental right. The provision of human dignity contains a constitutional view of a human being as an individual and the basic setting of a democratic society, according to which the state exists for a man/woman.

Human dignity is not a static standard ${ }^{15}$. Historically, the concept of human dignity appears in antiquity. Then the concept of dignity (lat. dignitas) played the role of social distinction, and represented a kind of a medal and award of honors that society, based on the value judgment or some objective reasons, awarded to an individual. Dignity belonged to the origins and functions, but it was also acquired by life achievements. Identification of dignity brought its holder the reputation and it required recognition of the environment through the expression of respect. Dignity was accompanied by a particular social position and rank, something that is not inherent to every individual. The concept of dignity did not refer to the logic of egalitarian equality but it was an expression of the logic of proportional justice, and was assigned according to the social position and merits. Furthermore, learnings of the Stoics and Christianity justify the notion of human dignity as a reflection of ones mind, morals and its divine origin. Human dignity is derived from the similarity of people with their creator. Special status of people stems from a divine gift through which they can create themselves and the world in which they live. A human being is born as a thinking being, and the creation of

\footnotetext{
${ }^{14}$ Article 1 of the Basic Law reads: "(1) Human dignity is inviolable. Every state authority is obliged to respect and protected it. (2) The German people therefore accept the inviolable and inalienable human rights as the foundation of every human community, peace and justice in the world. (3) The below mentioned basic rights, as directly applicable law, undertake legislative, executive and judicial power". In Article 1 of the Basic Law German people recognizes inviolable and inalienable human rights as the foundation of every human community, peace and justice in the world. The word "recognizes" here clearly indicates that the provision of Article 1 of the Basic Law is of declarative nature. It follows that fundamental rights exist prior to the addition of positive law. Likewise, H.C. Nipperdey believes that the article of fundamental rights represents "Norm höheren Rang, übergesetzliche Norm oder elementares Grundrecht". Such standards are related to the legislator, but also the framers of the Constitution. This belief has received a practical confirmation in case law see BVerfGE 1, 14 (61) or decision of the Bavarian Constitutional Court [10 june 1950, (104)]. See also: Neumann-Nipperdey-Scheuner, Die Grunrechte, Berlin 1954, p. 2; G. Düring, Der Grundrechtssatz von der Menschenwürde. Entwurf eines praktikablen Wertsystem der Grudrechte und art.1. Abs.1. in Verbindung mit Art.19. Abs.II. des Grundgesetze, in Archiv des öffentlichen Rechts, München, 81/1956, pp. 117-118.

15 The constitutional theory and practice wary from providing unique and comprehensive formulations of exact content of the concept of human dignity. It is always determined with description of its culture-specific image. The perception of the content of this concept is based on the totality of the constitutional guarantee of protection of the basic legal sphere of an individual that allows him to become, and remain to be a legal entitiy on the one hand and their relationship with the public interest or constitutionally protected individual interests of other people. Human dignity represents the normative idea of the individual as a person, which is marked by a culture of a society - see P. Häberle, Ustavna država, Zagreb, 2002, p. 122.
}

\section{CONSTITUTIONAL LAW REVIEW}




\section{Human dignity as a new constitutional value of the constitutional system...}

thought is the basis its dignity. Later, in the enlightened period concept of human dignity was explained by the human essennce and battle. Dignity is defined as a condition of purposes by itself, or as an absolute inner value that determines a human being ${ }^{16}$.

The above content undoubtedly does not coincide with that of human dignity as a constitutional category that it presently has. De lege lata et de lege ferenda, human dignity today is not related to human achievement or social status. The content of this concept on one hand is connected with the fact that an individual belongs to the human species, i.e. the biological type of human. Everything that is conceived by a human being, and what once was human has human dignity. On the other hand, human dignity is possessed by any incidence that has the ability to be a human, even when it comes to creation, which is explicitly under the law can not be considered a person, as is the case with the embryo. Human dignity is recognized to anyone who has the potential to be a humane and autonomous, it is recognized to everyone and to all people equally, to the same extent. Human dignity is not and can not accompany social rank or political importance of a person. Human dignity represents content that equally belongs to everyone and whose protection may be requested by anyone. It is a private and transpersonal category that on the side of an individual establishes an individual life sphere protected from encroachment by any person or entity. At the same time the human dignity of every individual constitutes a right to demand protection of its fundamental rights. The concept of human dignity can not be linked to an individual. This is because then its content would be identical with the content of the notion of a human ${ }^{17}$. Human dignity is possessed by every human and it is what determines a human being as an individual. It is contrary to human dignity to treat a human being as a

\footnotetext{
${ }^{16}$ See H. Ottman, Dostojanstvo čovjeka. Pitanja o neupitno priznatom pojmu, Politička misao, in Croatian political science review, Zagreb, vol. 34, no. 4/1997, pp. 32-35.

${ }^{17}$ BVerfGE 30,1 - "If the public authority which carries out the law treats a human so that it violated its human dignity, then it must be an expression of contempt of the values that belong to the human by the power of the fact that he is a person. (...) General formula as the one that a human being should not become the object of state power, can only suggests the direction of finding cases of violation of human dignity. Human being often is an ordinary object, not just of relations and social development, but also the law which, regardless of its own interests it must obey. In this fact we can not find a violation of human dignity. For a violation of human dignity, it is necessary that the man should be subjected to treatment that his personality principally puts in question, or that treatment in a particular case leads to an arbitrary abuse of human dignity. Treatment of a person by the public authority which carries out the law, when it would hurt the human dignity, must be an expression of belittling the values assigned to the person by the very fact that it is a person, that is, in this sense a «degrading treatment»".

From the dissenting opinion of judges Geller, Schlabrendorff and Rupp: "Human dignity can not be violated only in cases where the treatment of a person by public authorities is an expression of belittling the values that belong to that person by the power of the fact that it is a person, so in that sense a degrading treatment. If we approach it like that than the Article 79 para. (3) of the Basic Law is reduced to the prohibition of reintroducing such as abuse, nailing to the pillory and methods of the Third Reich. Such a restriction is not in line with the concept and spirit of the Basic Law. All state authorities are obliged to respect and protect the humans in their personal values, in their individuality. They should not be treated impersonally, as a subject, even when it does not happen for contempt of the person, but with best of intentions" - see G. Leibholz, Grundgesetz für die Bundesrepublike Deutchland, Komentar, Köln, 1993, Art.1. Rn. 3, or Maunz-Düring, Grundgesetz, Kommentar, München, 1999, Art. I. Rn. 19. i 21. See also BverfGE 39, 41.
} 


\section{Dubravko LJUBIĆ}

mere object of state power. Individual rights take precedence over the collectivity, whereby man must be and remain a goal in itself. Potentials and potential capabilities that make the human being are insufficient for the establishment of human dignity. The value of human dignity can not consist in its realization in a particular person, but in its potential abstract possibilities of realization ${ }^{18}$.

Human dignity is a constitutional category that determines each individual as a holder of rights and obligations arising from the basic norms. It is a constitutional legal term which has not been determined to be defined, and therefore limited. It lays the foundation on which a particular society can develop their legitimate interest to understand this concept broadly enough, separated from all dogmas, worldviews and anthropologies, as an expression of pure activity and the existence of a human. Human dignity on the one hand is the cause for which every individual is guaranteed a specific autonomous area protected from any outside influence, and thus the impact of the government itself. On the other hand, it is a reason and a limiting factor for state authorities in their relations with the individual. All individual rights and freedoms have their origin in human dignity. This is also the reason due to which there is and can be required a social protection of fundamental rights ${ }^{19}$. At the same time, human dignity represents the achieved and guaranteed minimum of non-derogable basic legal sphere of the individual. It is not subject to regression, nor any kind of limitation. It is an eternal value protected by a basic norm of the highest constitutional legal force 20 .

Therefore, generally speaking, human dignity is conceived as a barrier from the possibility that the laws can in an unbearable extent contradict the idea of justice, but it does not thereby lose its merits in basic standards. Human dignity is the right to independently design ones own life devoid of any interference of state authorities or various power centers. The power of basic norms can be derived only from the objective order of values, where human dignity as an ethical category must be the main pillar of social order. The content of human dignity is independent of subjective interpretations and perceptions and represents a real value system that may not even be the object of standardization. It exists by itself and is an inalienable part of every human being. Human dignity as an objective constitutional category sui generis

\footnotetext{
18 See BverfGE 5, 45 or 85, 187.

${ }^{19}$ H. Ottman, Dostojanstvo čovjeka, Pitanja o neupitno priznatom pojmu, Politička misao, in Croatian political science review, Zagreb, vol. 34, no. 4/1997, pp. 42-43 - "We might even be tempted to want to impose a definitional ban on «human dignity»". The concept of human dignity would lose its meaning and its significance if we deprive it of all its contents and its dogmatic value. A human can be defined as an anthropological creature who only has to interpreted and in that sense defined. But human dignity is what draws a boundary for every definition of a person. It must surely get rid of sharpened requirements for deserving the dignity with achievements of subjectivity. Human dignity is not only in what a person especially knows how or is able to achieve. It is reflected in what makes specific imperfections of a person. To be aware of these imperfections and act in accordance with them is also a sign of human dignity. It is human to do by with delusion, failure, guilt and sense of self-finality, it is also relevant to the dignity and the effects of modern subjectivity".

${ }^{20}$ Article 79 para. (3) of the Basic Law reads as follows: "Modification of the basic law that encroaches on (...) the principles set out in the provisions of Art. 1 (...) are inadmissible".
} 


\section{Human dignity as a new constitutional value of the constitutional system...}

determines the standardization of rights that arise from this feature, which must be devoid of any arbitrariness. The source of human dignity on the other hand is located in the culture of society, understood as the sum of all spiritual and material products of a social community. Human dignity is the basis of every legal order, its ethics and all the other factors that make a legal system just ${ }^{21}$. It is a conditio sine qua non of the existence of rights in general and an amendment to the concept of justice that has moved from the domain of mere egalitarianism into its full realization.

Juridically speaking, human dignity is achieved through the operationalization of the right to freedom and equality. Protecting of human dignity is also the protection of freedom and equality of the individual harmonized with the general interests and the rights of others. Therefore, it constitutes the primary object of constitutional protection. However, independent human dignity can not constitute a legal basis of the request for constitutional protection. It is not a basic human right, but it is the most constitutional principle contained within the basic content of all human rights and as such is not suitable $t$ be measured against the content of substantive constitutional rights. Human dignity is not a generic term for human rights, but their essential value that is characterized by inviolability and inalienability. Therefore, the provisions that protect the human dignity are the supreme norm of the existing legal system, the foundation of its morality and the basis of the system of values that it shapes.

In real-world effects of human dignity as the highest legal principle are reflected in giving directions to every action of the state government bodies in a way that in the relationship between the individual and the centers of power priority is always given to the individual. Inviolability of human dignity is absolute. It exists by itself and is not dependent upon activity of any entity of social relations. Inviolability of human dignity prevents primarily the state to make general and specific acts that would interfere with the untouchable sphere of each individual. Respect for human dignity on the other hand puts before the governmental bodies a claim to provide protection for the content of human dignity which may be affected by activities of other individuals and legal entities. Thus human dignity becomes the reason of defensive action not only of an individual, but of the state itself. In doing so, the state is not required to improve the content of the concept of human dignity, because it exists in itself. But when interpreting its contents the totality of the cultural range of a social community that knows the human dignity as the highest constitutional principle must be taken into account. For the protection of human dignity the essence of the problem is not finding the proportionality between two competing constitutionally protected goods, but there is

\footnotetext{
${ }^{21}$ Human dignity is an absolutely established tertium comparationis of any legal evaluation and judgment which makes perceptive and distinctive everything that must be understood as equal and therefore as absolutely equal - see G. Düring, Der Grundrechtssatz von der Menschenwürde. Entwurf eines praktikablen Wertsystem der Grudrechte und art.1. Abs.1. in Verbindung mit Art.19. Abs.II. des Grundgesetze, in Archiv des öffentlichen Rechts, München, 81/1956, p. 143.
} 


\section{Dubravko LJUBIĆ}

always an absolute prohibition of interference in the content of human dignity primarily by the state, but also all others ${ }^{22}$.

In addition to their constitutional components human dignity has its social component. It can not exist in societies that do not know the welfare state. This is because human dignity can be threatened in the event that an individual is living in conditions where it is not able to meet the basic needs regardless of whether these are minimal spiritual or physical necessities. From human dignity does not follow a priori obligation of the state to provide every individual with the right to basic material existence. But from it certainly stems the subjective right to public concern that should not be denied to anyone ${ }^{23}$. Human dignity, therefore, as a constitutional category becomes a shield of the individual from totalitarian and other kind of collectivism or from extreme individualism, allowing all its personalization. This is not a content that observes its holder separate from any social connections. Human dignity belongs to man as a person living in conditions of social interdependence, but in its essence it must not be sacrificed in order to achieve any collective goal. Human dignity is the mediating factor between pure individualism and any collectivism. It is a limit that prevents the society to step in objectively unwanted collectivism and serves as a dam from the arbitrariness of individuals or oligarchies. Human dignity is therefore the indispensable foundation of personal ethics that defines man as autonomous as well as a social being able to develop and occupy its place in society. Having human dignity means to be a person, while the property of being a person entails the responsibility to establish social relations ${ }^{24}$.

Human dignity is hurting when a person is degraded to the status of an object, a mere means or replaceable size. It distorts when centers can not deal with the individual as a man who has dignity as its purpose, but as a person who is a means to an end separated from its being ${ }^{25}$. Violations of human dignity may take the form of mass persecutions and genocide where the personality of a human being is reduced to the level of a thing. The same effect is caused by cruel sanctions that affect the spiritual and physical integrity of the individual. Human dignity is also threatened in cases of deprivation of legal personality where state actions consider a human only as an objects of state actions and rule. Human dignity is also infringed by an intrusion into the

\footnotetext{
22 See: G. Düring, Der Grundrechtssatz von der Menschenwürde. Entwurf eines praktikablen Wertsystem der Grudrechte und art.1. Abs.1. in Verbindung mit Art.19. Abs.II. des Grundgesetze, in Archiv des öffentlichen Rechts, München, 81/1956, pp. 4, 5, 18, 117; Maunz-Düring, Grundgesetz, Kommentar, München, 1999; Kommentirung der Artikel 1 ili Böckenförde, E.W/Spaemann, R; Menschenrechte und Menschenwürde, Institut für Wissenschaften von Menschen, Stuttgart, 1987, p. 307.

23 See G. Düring, Der Grundrechtssatz von der Menschenwürde. Entwurf eines praktikablen Wertsystem der Grudrechte und art.1. Abs.1. in Verbindung mit Art.19. Abs.II. des Grundgesetze, in Archiv des öffentlichen Rechts, München, 81/1956, pp. 21-22.

${ }^{24}$ See: G. Düring, Die Menschenauffassung des Grundgesetzes, in Juristische Rundschau no. 7/1952, pp. 259-261;

P. Häberle, Ustavna država,Politička kultura, Zagreb, 2002, pp. 122-132.

${ }^{25}$ See I. Kant, Zasnivanje metafizike morala, Beograd, 1981, p. 74.
} 
intimacy of man, blatant violations of the honor that prevent the continuation of life of the victim in its chosen habitus, as well as through social neglect in the case of a life of an individual in conditions below the subsistence minimum. Human dignity can be connected and with the principle of independence in a way that is seen to be at risk each time a person is, against its will, forced to devote an important part of its physical and spiritual integrity to the interests of others. Of course, the list of actions that can harm human dignity can never be made on the principle of numerus clausus. Each activity or omission in the basic legal sphere of an individual results in the loss of humanity and reduces a person to a level of a thing, and as its result has a content violation of human dignity. Human dignity before the legal system lays down a claim to shape social relations in a way that prevents violation of its contents by the state and all non-state actors, but also ensures the protection and justiciability of all subjective rights of human dignity arising at the constitutional and positive legal level. It belongs equally to social dignitaries and socially anonymous individuals. The existence of its infringement is not affected by consciousness or subjective knowledge of its holder on the existence of constitutionally unacceptable actions and omissions of the state or other natural or legal persons. Human dignity can be violated even if the holder knowingly agrees to prohibited acts of public authorities or of private persons. Human dignity also belongs to those who acted contrary to the dispositions of tort law, as well as those who have abused their rights. Criminal or other tort liability does not affect the minimum content of the concept of human dignity inherent in every human being. This is because the human dignity is a measure of the value of a human in general, rather than specific a measures of a human being. The holder of human dignity is every creation that has elements of humanity irrespective of differences in the definition of the duration of its biological life ${ }^{26}$. Human dignity can not be acquired by life and is independent of the characteristics of its holders associated with nationality, race, sex, religion, origin, education or with another socially conditioned fact. It belongs to people because of their understanding, self-awareness, and as a result of their work in the community and the effects on the environment in which they live. Human dignity in recent times is an indispensable foundation of human rights included in the constitutional and international documents ${ }^{27}$. And countries whose constitutions do not

\footnotetext{
${ }^{26}$ See BVerfGE 30,173; where human dignity is also recognized for dead people.

27 Article 1 of the Charter states: "Human dignity is inviolable. It must be respected and protected". As a minimum content of human dignity, Charter states the right to life; the right to physical and psychological identity, prohibition of torture and inhuman or degrading treatment; as well as the prohibition of slavery, forced labor and human trafficking. Article 10 of the Spanish Constitution reads: "Human dignity (...) is the foundation of political order and social peace". Article 3 para. (1) of the Italian Constitution reads: "All citizens have equal social dignity (...)". Article 2 para. (1) of the Greek Constitution reads: "The fundamental obligation of the state to respect and protect human dignity". Article 1 para. (3) of the Romanian Constitution reads: "Romania is a democratic and social state governed by the rule of law, in which human dignity, the citizens' rights and freedoms, the free development of human personality, justice and political pluralism represent supreme values, in the spirit of the Romanian people's democratic tradition and of the ideals embodied by the December 1989 Revolution, and shall be guaranteed". Provisions of similar content are also acknowledged by the Swedish, Portuguese and Turkish constitution.
}

CONSTITUTIONAL JURISDICTIONS 


\section{Dubravko LJUBIĆ}

know the institute of human dignity in their constitutional theory and practice, discuss it as a basis of the basic legal sphere, or as a starting point and a means of interpreting the content of constitutional rights ${ }^{28}$.

\section{Conclusions}

Human dignity inhibits the legislator to enact laws that can in an intolerable extent contradict the idea of justice, without thereby losing their merits in basic standards. The content of human dignity is independent of subjective interpretations and perceptions and represents a real value system that may not even be the object of standardization. It exists by itself and is an inalienable part of every human being. Human dignity as an objective constitutional category determines the standardization of rights that arise from this feature, which must be devoid of any arbitrariness. The source of human dignity on the other hand is located in the culture of society, understood as the sum of all spiritual and material products of a social community. Human dignity is the basis of every legal order, its ethics and all the other factors that make a legal system just. It is a condition for the existence of rights in general and an amendment to the concept of justice that has moved from the domain of mere egalitarianism into its full realization. Human dignity is a supplement to the notion of the rule of law and the welfare state, but also a prism through which we must repeatedly observe the compliance of positive law, and further legislative measures with the requirements before the legal system by the Constitution based on human dignity as a starting premise of the existence and protection of the basic legal sphere. Croatian Constitution does not recognize human dignity as the highest value and the basis of design of the basic legal sphere. By accepting the Charter of Fundamental Rights of the European Union human dignity is not becoming just the source and means of interpretation of the basic legal sphere, but it is also becoming the basis for establishing relations between the individual and the state and individuals themselves.

\footnotetext{
28 The US Constitution does not recognize human dignity but it is elaborated in theory and practice. See R. Dworkin, Shvaćanje prava ozbiljno, KruZak, Zagreb, 2003, pp. 142-146, and Decisions SC-USA Roe v. Wade 410 U.S.113 (1973) or Doe v. Bolton 410 U.S. 179 (1973).
} 